\title{
IMPLEMENTASI JARINGAN SYARAF TIRUAN PERAMBATAN BALIK UNTUK MEMPREDIKSI HARGA LOGAM MULIA EMAS MENGGUNAKAN ALGORITMA LEVENBERG MARQUARDT
}

\author{
Reza Najib Hidayat ${ }^{1}$, R. Rizal Isnanto ${ }^{2}$, Oky Dwi Nurhayati ${ }^{2}$
}

Abstract

Gold is one of commodities investment which its value continue to increase by year. The rising price of gold will encourage investors to choose to invest in gold rather than the stock market. With the risks that are relatively low, gold can give better resultsin accordance with its increasing price. In addition, gold can also be a safe value protector in the future.The Objectives of the research are to predict the price of gold using artificial neural networks backpropagations methods and to analyze best network used in prediction.

In the process of training data, it is used some training parameters to decide the best gold prediction architecture. Comparative parameters that is used are the variation of the number of hidden layers, number of neurons in each hidden layer, learning rate, minimum gradients and fault tolerance.

The results showed that the best architecture has an accuracy rate of 99,7604\% of data training and test data at 98,849\% with architecture combinations are have two hidden layer neurons combined 10-30, the error rate 0.00001 and 0.00001 of learning rate.

\section{Index Terms : Prediction, Gold, Artificial Neural Networks, Backpropagation.}

\section{Pendahuluan}

Kegiatan ekonomi di dunia ini tidak dapat dilepaskan dari kegiatan investasi karena dengan adanya investasi akan mendorong pertumbuhan ekonomi suatu negara. Logam mulia emas merupakan salah satu komoditas investasi yang nilainya terus mengalami kenaikan dari tahun ke tahun. Kenaikan harga emas ini akan mendorong investor untuk memilih berinvestasi emas daripada pasar modal. Investasi dalam emas memberikan hasil yang lebih baik untuk jangka panjang dan dengan daya beli (purchasing power) yang lebih baik, sehingga investasi emas merupakan solusi efektif mengingat nilai uang yang setiap tahun tergerus oleh inflasi. Inflasi merupakan suatu gejala yang terjadi karena adanya ketidakstabilan ekonomi sehingga harga mengalami kenaikan secara kontinu. Keadaan seperti ketidakstabilan ekonomi inilah yang mendorong banyak orang, organasi dan perusahaan untuk berinvestasi logam mulia emas.

1. Mahasiswa Program Studi Sistem Komputer, Fakultas Teknik, Universitas Diponegoro. Jl. Prof. Soedarto Tembalang, Semarang-Indonesia. rezanajib88@gmail.com

2. Dosen Program Studi Sistem Komputer, Fakultas Teknik, Universitas Diponegoro. Jl. Prof. Soedarto Tembalang, Semarang-Indonesia.
Berdasarkan permasalahan di atas, kemampuan untuk dapat memprediksi harga logam mulia emas merupakan keuntungan tersendiri untuk melindungi diri dari dampak inflasi, sehingga timbul ide untuk merancang sebuah aplikasi yang dapat digunakan untuk memprediksi harga logam mulia emas menggunakan metode Jaringan Syaraf Tiruan.

Tujuan dari penelitian ini diantaranya sebagai berikut.

1. Memprediksi harga logam mulia emas untuk satu hari kedepan.

2. Memberikan pilihan solusi untuk investor dalam melakukan investasi logam mulia emas.

3. Menganalisis tingkat akurasi prediksi harga logam mulia emas menggunakan JST perambatan balik dengan algoritma Levenberg Marquardt.

\section{Dasar Teori}

\subsection{Jaringan Syaraf Tiruan (JST)}

Jaringan syaraf tiruan (JST), adalah sistem komputasi di mana arsitektur dan operasi diilhami dari pengetahuan tentang sel syaraf biologis di dalam otak, yang merupakan salah satu representasi buatan dari otak manusia yang selalu mencoba menstimulasi proses pembelajaran pada otak manusia tersebut. JST dapat digambarkan sebagai model matematis dari model syaraf biologi. Model syaraf ditunjukkan dengan kemampuannya dalam emulasi, analisis, 
prediksi dan asosiasi. JST ditentukan oleh tiga hal, yaitu arsitektur jaringan, metode pelatihan dan fungsi aktivasi. Berikut merupakan contoh arsitektur jaringan sederhana yang ditunjukkan pada Gambar 1 .

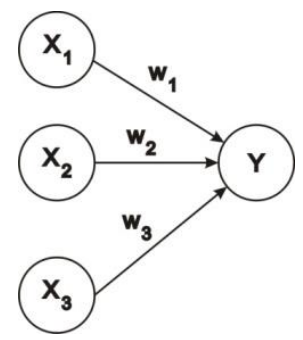

Gambar 1 Contoh Arsitektur Jaringan Sederhana

Keterangan :

Neuron masukan : $X 1, X 2, X 3$

Bobot : $W 1, W 2, W 3$

Neuron Keluaran : $Y$

$Y$ menerima masukan dari neuron $X 1, X 2, X 3$ dengan bobot hubungan masing-masing adalah $W l$, $W 2$, W3. Ketiga impuls neuron yang ada dijumlahkan (net $=\mathrm{X} 1 \mathrm{~W} 1+X 2 W 2+X 3 W 3)$. Besarnya impuls yang diterima oleh $Y$ mengikuti fungsi aktivasi, $y=$ $f(n e t)$. Apabila nilai fungsi aktivasi cukup kuat, maka sinyal akan diteruskan. Nilai fungsi aktivasi (keluaran model jaringan) juga dapat dipakai sebagai dasar untuk mengubah bobot.

\subsection{Jaringan Syaraf Tiruan Perambatan Balik}

Perambatan balik merupakan algoritma pembelajaran yang terawasi dan biasanya digunakan oleh perseptron dengan banyak lapisan untuk mengubah bobot-bobot yang terhubung dengan neuron-neuron yang ada pada lapisan tersembunyinya. Jaringan perambatan galat mundur merupakan salah satu algoritma yang sering digunakan dalam menyelesaikan masalah-masalah yang rumit. Hal ini dimungkinkan karena jaringan dengan algoritma ini dilatih dengan menggunakan metode belajar terbimbing. Pada jaringan diberikan sepasang pola yang terdiri atas pola masukan dan pola yang diinginkan. Ketika suatu pola diberikan kepada jaringan, bobot-bobot diubah untuk memperkecil perbedaan pola keluaran dan pola yang diinginkan. Latihan ini dilakukan berulang-ulang sehingga semua pola yang dikeluarkan jaringan dapat memenuhi pola yang diinginkan.

Algoritma pelatihan jaringan syaraf perambatan galat mundur terdiri atas dua langkah, yaitu perambatan maju dan perambatan mundur. Langkah perambatan maju dan perambatan mundur ini dilakukan pada jaringan untuk setiap pola yang diberikan selama jaringan mengalami pelatihan

\subsection{Arsitektur Perambatan Balik}

Perambatan balik memiliki beberapa unit yang ada dalam satu atau lebih lapisan tersembunyi. Pada
Gambar 2 menunjukkan arsitektur perambatan balik dengan $n$ buah masukan (ditambah sebuah bias), sebuah lapisan tersembunyi yang terdiri dari $p$ unit (ditambah sebuah bias), serta $m$ unit keluaran.

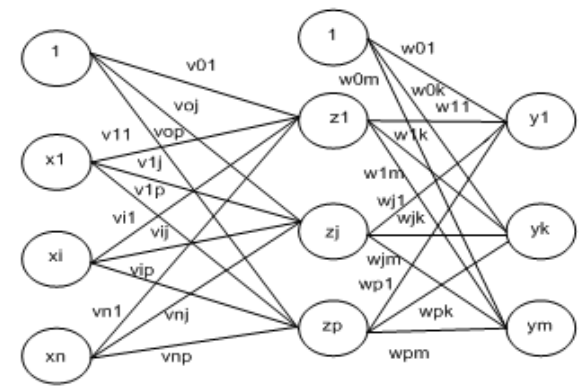

Gambar 2 Arsitektur Jaringan Perambatan Balik

Vji merupakan bobot garis dari unit masukan $X i$ ke unit lapisan tersembunyi $\mathrm{Zj}$ ( $\mathrm{VjO}$ merupakan bobot garis yang menghubungkan bias di unit masukan ke unit lapisan tersembunyi $Z j$ ). Wkj merupakan bobot dari unit lapisan tersembunyi $Z j$ ke unit keluaran $Y k$ (WkO merupakan bobot dari bias di lapisan tersembunyi ke unit keluaran $Z k$ ).

\subsection{Algoritma Pembelajaran Levenberg Marquardt}

Algoritma levenberg marquardt merupakan pengembangan algoritma perambatan balik standar, pada algoritma standar proses perubahan bobot dan bias menggunakan negative gradient descent secara langsung sedangkan algoritma levenberg marquardt menggunakan pendekatan matrik hesian $(\mathrm{H})$ pada perubahan bobot dan biasnya yang dapat dihitung dengan

$$
H=J^{T} e
$$

Sedangkan gradient dapat dihitung dengan

$$
g=J^{T} J
$$

Dalam hal ini $J$ merupakan matrik jacobian yang berisikan turunan pertama dari error jaringan terhadap bobot dan bias jaringan. Perubahan bobot dapat dihitung dengan

$$
\Delta X=\left[J^{T} J+\mu I\right]^{-} J^{T} e
$$

Sehingga perbaikan bobot dapat ditentukan dengan

$$
\begin{aligned}
& X=X+\Delta X \\
& X=\Delta X+\left[J^{T} J+\mu I\right]^{-} J^{T} e
\end{aligned}
$$

$X=$ fungsi bobot-bobot jaringan dan bias

$X=\left[V_{11}, V_{12}, \ldots . V_{i j} ; V_{11}, V_{01}, V_{02}, \ldots . V_{0 j}\right.$,

$\left.; W_{11}, W_{12}, \ldots . W_{k j} ; W_{01}, W_{02} \ldots . W_{0 k}\right]$

$e$ adalah vektor yang menyatakan semua error pada output jaringan

$$
e=\left[t_{1}-Y_{1} t_{2}-Y_{2} \ldots . t_{p}-Y_{p}\right]^{T} . . \text { (2.6) }
$$

$\mu=$ laju pembelajaran $; I=$ matrik identitas

\section{Metodologi Penelitian}

Aplikasi jaringan syaraf tiruan untuk memprediksi harga logam mulia ini merupakan sistem yang dapat digunakan untuk meramalkan harga logam mulia untuk satu hari ke depan. Jaringan syaraf 
digunakan untuk mengenali pola data pergerakan harga logam mulia.

Data diperoleh dari http://antamgold.com. Kemudian data dibagi menjadi $60 \%$ data latih dan $40 \%$ data uji. Data latih merupakan data yang digunakan dalam proses pelatihan dan data uji merupakan data yang digunakan dalam proses pengujian (tidak digunakan dalam proses pelatihan).

Setiap basis data kemudian diolah terlebih dahulu dengan melakukan proses normalisasi. Proses selanjutnya adalah melatihkan basis data tersebut ke dalam jaringan syaraf tiruan. Data masukan diumpankan ke dalam jaringan untuk diolah, kemudian hasil pengolahan tersebut akan dibandingkan dengan target yang sebelumnya telah ditentukan. Proses pelatihan ini dibatasi oleh parameter-parameter pelatihan yang diinginkan. Setelah dilatih, sistem akan menyimpan jaringan tersebut sesuai dengan parameter pelatihan yang digunakan. Jaringan yang telah dilatih dan disimpan tersebut kemudian dapat diketahui kemampuannya dalam mengenali data latih. Kemampuan jaringan dalam mengenali data latih ini dapat menjadi acuan untuk kelayakan jaringan dalam mengenali data, terutama dalam proses peramalan.

Data diperoleh dari http://antamgold.com, merupakan harga logam mulia harian terhitung mulai tanggal 1 Januari 2012 sampai 31 Oktober 2012 (dalam rupiah). Data yang telah diperoleh kemudian dibagi menjadi dua yaitu sebagai data latih dan sebagai data uji. Pembagian data latih sebesar $60 \%$ dan data uji sebesar $40 \%$, sehingga memilki data uji sebanyak 178 pasang data dan data uji sebanyak 108 pasang data.

Pembuatan basis data ini berlaku untuk data latih dan data uji, namun data yang dipakai dalam proses pelatihan adalah data latih, sedangkan data uji digunakan sebagai masukan dan peramalan harga untuk kemudian hasil peramalan dicocokan dengan target yang ada.

Data dibuat menjadi 10 masukan dan 1 buat target untuk satu data. Harga masukan merupakan harga 10 hari sebelum data yang akan diramal. Sedangkan target merupakan harga yang akan diramal pada 1 hari kedepan. Jika harga logam mulia dimulai dengan hari ke-1 sampai ke-10, maka target dan hari yang akan diramal adalah hari ke-11. Jika masukan mulai dengan harga hari ke-2 sampai hari ke-11, maka target dan hari yang akan diramal adalah hari ke-12, begitu seterusnya lalu disimpan dalam format *.mat

Untuk merancang jaringan sebagai pola pelatihan, ditentukan terlebih dahulu parameter-parameter masukan sehingga peramalan dapat dilakukan.

Algoritma yang digunakan adalah perambatan balik dengan pembelajaran terbimbing sehingga membutuhkan data masukan dan data target. Berikut merupakan rancangan program yang terdapat dalam penelitian ini adalah
1. Lapisan Masukan : terdiri atas satu lapisan dengan 10 neuron yang merupakan harga dari logam mulia 10 hari sebelumnya.

2. Lapisan tersembunyi : terdiri atas dua pilihan lapisan tersembunyi yaitu satu lapisan tersembunyi dan dua lapisan tersembunyi dengan neuron yang bervariasi sesuai dengan masukan dari pengguna.

3. Lapisan keluaran : terdiri atas satu lapis dengan satu neuron yang merupakan target atau keluaran dari peramalan.

Selanjutnya kita lakukan pelatihan jaringan yang bertujuan untuk mendapatkan nilai bobot terbaik yang digunakan sebagai acuan bagi masukan data pada peramalan. Pola masukan dirambatkan melalui lapisan masukan sampai lapisan keluaran, lalu akan dicocoklan dengan keluaran target awal. Jika terdapat perbedaan nilai diantara keduanya, ini yang disebut dengan galat dan galat tersebut dapat kita atur nilainya, sehingga sebelum nilai galat sesuai dengan yang diinginkan maka pelatihan akan terus dilakukan.

Dalam pelatihan jaringan ini, terdapat beberapa parameter untuk mendapatkan hasil yang terbaik. Parameter-parameter tersebut, antara lain :

1. net.trainParam.epochs

Merupakan parameter yang berfungsi untuk menentukan jumlah maksimum iterasi yang diinginkan. Besar nilai menentukan hasil yang dicapai. Jika nilai iterasi ditentukan sebesar 1000, maka pelatihan akan dihentikan ketika nilai iterasi telah mencapai 1000 atau nilai parameter lainnya telah tercapai.

2. net.trainParam.goal

Merupakan parameter yang berfungsi untuk menentukan target galat pada pelatihan jaringan. Jika menentukan galat sebesar 0,00001, maka pelatihan akan berhenti ketika target galat telah mencapai 0,00001 atau nilai dari parameter lain telah tercapai.

3. net.trainParam.lr

Merupakan parameter yang berfungsi untuk menentukan besar laju pembelajaran pada jaringan yang memiliki besaran nilai antara 0-1.

4. net.trainParam.min_grad

Merupakan parameter yang menentukan batas gradient minimum yang dicapai pada saat pelatihan jaringan.

Parameter-parameter tersebut saling berkaitan satu sama lain sehingga yang pelatihan akan dihentikan jika salah satu nilai telah terpenuhi, dan pelatihan di sini menggunakan cara trial and error sehingga kita harus mengkombinasikan parameterparameter tersebut untuk mencapai nilai target.

\section{Hasil Penelitian dan Pembahasan}

\subsection{Pengujian Data Latih}

Dalam pengujian data latih digunakan beberapa kombinasi antara lain : 
1. Menggunakan nilai parameter default yaitu dengan nilai target/toleransi kesalahan sebesar 0 , laju pembelajaran bernilai 0,01 dan gradien minimum sebesar $1,00 \times 10^{-10}$.

2. Dari nilai default, menambahkan nilai toleransi menjadi 0,0001, memperbesar nilai laju pembelajaran menjadi 0,3 .

3. Lalu merubah nilai toleransi menjadi 0,00001 untuk lebih memperkecil galat yang akan memberikan hasil tingkat akurasi yang lebih tinggi, menggunakan variasi nilai laju pembelajaran sebesar 0,$001 ; 0,0001$ dan 0,00001 untuk mengetahui apakah nilai laju pembelajaran mempengaruhi hasil tingkat akurasi dan merubah nilai gradien miminum menjadi sebesar $1,00 \times$ $10^{-7}$.

Untuk semua nilai parameter tersebut menggunakan variasi jumlah lapisan tersembunyi dan kombinasi jumlah neuron untuk mengetahui arsitektur seperti apakah yang paling baik untuk pelatihan data tersebut.

\subsection{Pengujian Data Latih Satu Lapisan Tersembunyi}

Pengujian data latih satu lapisan tersembunyi merupakan pengujian yang dilakukan untuk melihat hasil akurasi yang dihasilkan setelah data melalui proses pelatihan. Tabel 1 berikut merupakan hasil pengujian data latih dengan satu lapisan tersembunyi.

Tabel 1. Hasil Pengujian Data Latih Satu Lapisan Tersembunyi

\begin{tabular}{|c|c|c|c|c|c|}
\hline \multirow{2}{*}{ No. } & \multicolumn{4}{|c|}{ Parameter Pelatihan } & \multirow{2}{*}{$\begin{array}{c}\text { Hasil } \\
\text { Akurasi } \\
(\%)\end{array}$} \\
\hline & Neuron & Galat & $\begin{array}{c}\text { Laju } \\
\text { Pembelajaran } \\
\end{array}$ & $\begin{array}{c}\text { Gradien } \\
\text { Minimum }\end{array}$ & \\
\hline 1 & 10 & 0 & 0,01 & $1,00 \times 10^{-10}$ & 99,900 \\
\hline 2 & 10 & 0 & 0,3 & $1,00 \times 10^{-10}$ & 99,899 \\
\hline 3 & 10 & 0,0001 & 0,01 & $1,00 \times 10^{-10}$ & 99,404 \\
\hline 4 & 10 & 0,0001 & 0,3 & $1,00 \times 10^{-10}$ & 99,330 \\
\hline 5 & 10 & 0,00001 & 0,00001 & $1,00 \times 10^{-7}$ & 99,771 \\
\hline 6 & 10 & 0,00001 & 0,0001 & $1,00 \times 10^{-7}$ & 99,756 \\
\hline 7 & 10 & 0,00001 & 0,001 & $1,00 \times 10^{-7}$ & 99,766 \\
\hline 8 & 20 & 0 & 0,01 & $1,00 \times 10^{-10}$ & 100 \\
\hline 9 & 20 & 0 & 0,3 & $1,00 \times 10^{-10}$ & 100 \\
\hline 10 & 20 & 0,0001 & 0,01 & $1,00 \times 10^{-10}$ & 99,326 \\
\hline 11 & 20 & 0,0001 & 0,3 & $1,00 \times 10^{-10}$ & 99,361 \\
\hline 12 & 30 & 0,00001 & 0,00001 & $1,00 \times 10^{-7}$ & 99,757 \\
\hline 13 & 30 & 0,00001 & 0,0001 & $1,00 \times 10^{-7}$ & 99,765 \\
\hline 14 & 30 & 0,00001 & 0,001 & $1,00 \times 10^{-7}$ & 99,762 \\
\hline 15 & 50 & 0,00001 & 0,00001 & $1,00 \times 10^{-7}$ & 99,755 \\
\hline 16 & 50 & 0,00001 & 0,0001 & $1,00 \times 10^{-7}$ & 99,763 \\
\hline 17 & 50 & 0,00001 & 0,001 & $1,00 \times 10^{-7}$ & 99,751 \\
\hline 18 & 70 & 0,00001 & 0,00001 & $1,00 \times 10^{-7}$ & 99,756 \\
\hline 19 & 70 & 0,00001 & 0,0001 & $1,00 \times 10^{-7}$ & 99,763 \\
\hline 20 & 70 & 0,00001 & 0,001 & $1,00 \times 10^{-7}$ & 99,763 \\
\hline 21 & 90 & 0,00001 & 0,00001 & $1,00 \times 10^{-7}$ & 99,763 \\
\hline 22 & 90 & 0,00001 & 0,0001 & $1,00 \times 10^{-7}$ & 99,767 \\
\hline 23 & 90 & 0,00001 & 0,001 & $1,00 \times 10^{-7}$ & 99,777 \\
\hline
\end{tabular}

Dari Tabel 1 bisa kita lihat bahwa hasil tingkat akurasi terbaik mencapai $100 \%$ yaitu pada kombinasi satu lapisan tersembunyi dengan jumlah neuron 20, galat 0 dan laju pembelajaran masing-masing bernilai 0,01 dan 0,3. Sedangkan hasil tingkat akurasi terendah sebesar 99,241\% dengan kombinasi jumlah neuron 20, galat 0,0001 dan laju pembelajaran bernilai 0,3.Pada kasus tersebut, hasil akurasi terbaik maupun hasil akurasi terendah memiliki jumlah neuron yang sama yaitu berjumlah 20, hal tersebut menunjukkan bahwa jumlah neuron tidak mempengaruhi tingkat akurasi data.

Pada hasil akurasi terbaik, memiliki galat 0 dan pada hasil akurasi terendah memiliki galat bernilai 0,0001, hal tersebut menunjukkan bahwa nilai parameter galat mempengaruhi hasil tingkat akurasi data. Lalu untuk nilai parameter laju pembelajaran, pada hasil akurasi terbaik memiliki nilai sebesar 0,01 dan 0,3 , begitu juga dengan nilai parameter pada hasil akurasi terendah yang memiliki nilai laju pembelajaran sebesar 0,3 , hal tersebut menunjukkan bahwa laju pembelajaran tidak mempengaruhi tingkat akurasi data.Untuk parameter nilai gradien minimum, kedua hasil tersebut memiliki nilai yang sama yaitu sebesar $1,00 \times 10^{-10}$ yang berarti nilai gradien minimum tidak mempengaruhi hasil tingkat akurasi data pelatihan

\subsection{Pengujian Data Latih Dua Lapisan Tersembunyi}

Pengujian data latih dua lapisan tersembunyi merupakan pengujian untuk melihat hasil akurasi data latih. Jika sebelumnya memiliki satu lapisan tersembunyi, kali ini jaringan memiliki dua lapisan tersembunyi. Hal ini dilakukan untuk mengetahui apakah penambahan lapisan tersembunyi berpengaruh terhadap akurasi data atau tidak yang ditunjukkan pada Tabel 2 berikut.

Tabel 2 Hasil Pengujian Data Latih Dua Lapisan Tersembunyi

\begin{tabular}{|c|c|c|c|c|c|c|}
\hline \multirow{2}{*}{ No. } & \multicolumn{7}{|c|}{ Parameter Pelatihan } & $\begin{array}{c}\text { Hasil } \\
\text { Akurasi } \\
(\%)\end{array}$ \\
\cline { 2 - 6 } & $\begin{array}{c}|c| \\
\text { Lapisan } \\
\text { Tersembunyi }\end{array}$ & Galat & $\begin{array}{c}\text { Laju } \\
\text { Pembelajaran }\end{array}$ & $\begin{array}{c}\text { Gradien } \\
\text { Minimum }\end{array}$ & \\
\cline { 2 - 6 } & I & II & & 0,01 & $1,00 \times 10^{-10}$ & 100 \\
\hline 1 & 10 & 10 & 0 & 0,3 & $1,00 \times 10^{-10}$ & 100 \\
\hline 2 & 10 & 10 & 0 & 0,01 & $1,00 \times 10^{-10}$ & 99,179 \\
\hline 3 & 10 & 10 & 0,0001 & 0,3 & $1,00 \times 10^{-10}$ & 99,512 \\
\hline 4 & 10 & 10 & 0,0001 & $1,00 \times 10^{-7}$ & 99,784 \\
\hline 5 & 10 & 10 & 0,00001 & 0,00001 & $1,00 \times 10^{-7}$ & 99,779 \\
\hline 6 & 10 & 10 & 0,00001 & 0,0001 & $1,00 \times 10^{-7}$ & 99,780 \\
\hline 7 & 10 & 10 & 0,00001 & 0,001 & $1,00 \times 10^{-10}$ & 100 \\
\hline 8 & 10 & 20 & 0 & 0,01 & $1,00 \times 10^{-10}$ & 100 \\
\hline 9 & 10 & 20 & 0 & 0,3 & $1,00 \times 10^{-10}$ & 99,284 \\
\hline 10 & 10 & 20 & 0,0001 & 0,01 & $1,00 \times 10^{-10}$ & 99,248 \\
\hline 11 & 10 & 20 & 0,0001 & 0,3 & $1,00 \times 10^{-7}$ & 99,760 \\
\hline 12 & 10 & 30 & 0,00001 & 0,00001 & $1,00 \times 10^{-7}$ & 99,762 \\
\hline 13 & 10 & 30 & 0,00001 & 0,0001 & $1,00 \times 10^{-7}$ & 99,766 \\
\hline 14 & 10 & 30 & 0,00001 & 0,001 & $1,00 \times 10^{-7}$ & 99,771 \\
\hline 15 & 10 & 50 & 0,00001 & 0,00001 & 1 & \\
\hline & & & & & & \\
\hline
\end{tabular}


Tabel 2 Hasil Pengujian Data Latih Dua Lapisan Tersembunyi (Lanjutan)

\begin{tabular}{|c|c|c|c|c|c|c|}
\hline \multirow{3}{*}{ No. } & \multicolumn{5}{|c|}{ Parameter Pelatihan } & \multirow{3}{*}{$\begin{array}{l}\text { Hasil } \\
\text { Akurasi } \\
(\%)\end{array}$} \\
\hline & \multicolumn{2}{|c|}{$\begin{array}{c}\text { Lapisan } \\
\text { Tersembunyi }\end{array}$} & \multirow[t]{2}{*}{ Galat } & \multirow[t]{2}{*}{$\begin{array}{c}\text { Laju } \\
\text { Pembelajaran }\end{array}$} & \multirow[t]{2}{*}{$\begin{array}{l}\text { Gradien } \\
\text { Minimum }\end{array}$} & \\
\hline & I & II & & & & \\
\hline 16 & 10 & 50 & 0,00001 & 0,0001 & $1.00 \times 10^{-7}$ & 99,770 \\
\hline 17 & 10 & 50 & 0,00001 & 0,001 & $1.00 \times 10^{-7}$ & 99,771 \\
\hline 18 & 20 & 10 & 0 & 0,01 & $1.00 \times 10^{-10}$ & 100 \\
\hline 19 & 20 & 10 & 0 & 0,3 & $1.00 \times 10^{-10}$ & 100 \\
\hline 20 & 20 & 10 & 0,0001 & 0,01 & $1,00 \times 10^{-20}$ & 99,210 \\
\hline 21 & 20 & 10 & 0,0001 & 0,3 & $1,00 \times 10^{-10}$ & 99,335 \\
\hline 22 & 20 & 20 & 0 & 0,01 & $1.00 \times 10^{-10}$ & 100 \\
\hline 23 & 20 & 20 & 0 & 0,3 & $1.00 \times 10^{-10}$ & 100 \\
\hline 24 & 20 & 20 & 0,0001 & 0,01 & $1.00 \times 10^{-20}$ & 99,399 \\
\hline 25 & 20 & 20 & 0,0001 & 0,3 & $1.00 \times 10^{-10}$ & 99,207 \\
\hline 26 & 30 & 10 & 0,00001 & 0,00001 & $1.00 \times 10^{-7}$ & 99,763 \\
\hline 27 & 30 & 10 & 0,00001 & 0,0001 & $1.00 \times 10^{-7}$ & 99,763 \\
\hline 28 & 30 & 10 & 0,00001 & 0,001 & $1.00 \times 10^{-7}$ & 99,762 \\
\hline 29 & 30 & 30 & 0,00001 & 0,00001 & $1.00 \times 10^{-7}$ & 99,772 \\
\hline 30 & 30 & 30 & 0,00001 & 0,0001 & $1.00 \times 10^{-7}$ & 99,767 \\
\hline 31 & 30 & 30 & 0,00001 & 0,001 & $1.00 \times 10^{-7}$ & 99,774 \\
\hline 32 & 30 & 50 & 0,00001 & 0,00001 & $1,00 \times 10^{-7}$ & 99,773 \\
\hline 33 & 30 & 50 & 0,00001 & 0,0001 & $1,00 \times 10^{-7}$ & 99,774 \\
\hline 34 & 30 & 50 & 0,00001 & 0,001 & $1,00 \times 10^{-7}$ & 99,785 \\
\hline 35 & 50 & 10 & 0,00001 & 0,00001 & $1.00 \times 10^{-7}$ & 99,767 \\
\hline 36 & 50 & 10 & 0,00001 & 0,0001 & $1.00 \times 10^{-7}$ & 99,760 \\
\hline 37 & 50 & 10 & 0,00001 & 0,001 & $1.00 \times 10^{-7}$ & 99,767 \\
\hline 38 & 50 & 30 & 0,00001 & 0,00001 & $1.00 \times 10^{-7}$ & 99,758 \\
\hline 39 & 50 & 30 & 0,00001 & 0,0001 & $1.00 \times 10^{-7}$ & 99,759 \\
\hline 40 & 50 & 30 & 0,00001 & 0,001 & $1.00 \times 10^{-7}$ & 99,776 \\
\hline 41 & 50 & 50 & 0,00001 & 0,00001 & $1.00 \times 10^{-7}$ & 99,776 \\
\hline 42 & 50 & 50 & 0,00001 & 0,0001 & $1,00 \times 10^{-7}$ & 99,845 \\
\hline 43 & 50 & 50 & 0,00001 & 0,001 & $1.00 \times 10^{-7}$ & 99,768 \\
\hline 44 & 70 & 10 & 0,00001 & 0,00001 & $1,00 \times 10^{-7}$ & 99,764 \\
\hline 45 & 70 & 10 & 0,00001 & 0,0001 & $1,00 \times 10^{-7}$ & 99,765 \\
\hline 46 & 70 & 10 & 0,00001 & 0,001 & $1,00 \times 10^{-7}$ & 99,770 \\
\hline 47 & 70 & 30 & 0,00001 & 0,00001 & $1,00 \times 10^{-7}$ & 99,771 \\
\hline 48 & 70 & 30 & 0,00001 & 0,0001 & $1,00 \times 10^{-7}$ & 99,780 \\
\hline 49 & 70 & 30 & 0,00001 & 0,001 & $1,00 \times 10^{-7}$ & 99,781 \\
\hline 50 & 70 & 50 & 0,00001 & 0,00001 & $1,00 \times 10^{-7}$ & 99,786 \\
\hline 51 & 70 & 50 & 0,00001 & 0,0001 & $1,00 \times 10^{-7}$ & 99,768 \\
\hline 52 & 70 & 50 & 0,00001 & 0,001 & $1,00 \times 10^{-7}$ & 99,766 \\
\hline 53 & 90 & 10 & 0,00001 & 0,00001 & $1,00 \times 10^{-7}$ & 99,789 \\
\hline 54 & 90 & 10 & 0,00001 & 0,0001 & $1,00 \times 10^{-7}$ & 99,775 \\
\hline 55 & 90 & 10 & 0,00001 & 0,001 & $1,00 \times 10^{-7}$ & 99,771 \\
\hline 56 & 90 & 30 & 0,00001 & 0,00001 & $1,00 \times 10^{-7}$ & 99,783 \\
\hline 57 & 90 & 30 & 0,00001 & 0,0001 & $1,00 \times 10^{-7}$ & 99,795 \\
\hline 58 & 90 & 30 & 0,00001 & 0,001 & $1.00 \times 10^{-7}$ & 99,762 \\
\hline 59 & 90 & 50 & 0,00001 & 0,00001 & $1,00 \times 10^{-7}$ & 99,766 \\
\hline 60 & 90 & 50 & 0,00001 & 0,0001 & $1.00 \times 10^{-7}$ & 99,783 \\
\hline 61 & 90 & 50 & 0,00001 & 0,001 & $1.00 \times 10^{-7}$ & 99.763 \\
\hline
\end{tabular}

Pada satu lapisan tersembunyi, hasil akurasi terendah mencapai $99,241 \%$ sedangkan pada jaringan dua lapisan tersembunyi mencapai 99, 179\%. Hal tersebut menunjukkan bahwa penambahan jumlah lapisan tersembunyi tidak berbanding lurus terhadap peningkatan akurasi data.

\subsection{Pengujian Data Uji Satu Lapisan Tersembunyi}

Pengujian data uji dilakukan untuk mengetahui kemampuan jaringan dalam memprediksi harga logam mulia yang sebenarnya dengan menggunakan data baru yang disebut sebagai data uji. Tabel 3 menunjukkan hasil pengujian data uji dengan satu lapis tersembunyi.

Tabel 3 Hasil Pengujian Data Uji Satu Lapis Tersembunyi

\begin{tabular}{|c|c|c|c|c|c|}
\hline \multirow{2}{*}{ No. } & \multicolumn{4}{|c|}{ Parameter Pelatihan } & \multirow{2}{*}{$\begin{array}{c}\text { Hasil } \\
\text { Akurasi } \\
(\%)\end{array}$} \\
\hline & Neuron & Galat & $\begin{array}{c}\text { Laju } \\
\text { Pembelajaran }\end{array}$ & $\begin{array}{c}\text { Gradien } \\
\text { Minimum }\end{array}$ & \\
\hline 1 & 10 & 0 & 0,01 & $1,00 \times 10^{-10}$ & 53,886 \\
\hline 2 & 10 & 0 & 0,3 & $1,00 \times 10^{-10}$ & 82,736 \\
\hline 3 & 10 & 0,0001 & 0,01 & $1,00 \times 10^{-10}$ & 97,533 \\
\hline 4 & 10 & 0,0001 & 0,3 & $1,00 \times 10^{-10}$ & 95,817 \\
\hline 5 & 10 & 0,00001 & 0,00001 & $1,00 \times 10^{-7}$ & 92,849 \\
\hline 6 & 10 & 0,00001 & 0,0001 & $1,00 \times 10^{-7}$ & 93,931 \\
\hline 7 & 10 & 0,00001 & 0,001 & $1,00 \times 10^{-7}$ & 94,787 \\
\hline 8 & 20 & 0 & 0,01 & $1,00 \times 10^{-10}$ & 59,892 \\
\hline 9 & 20 & 0 & 0,3 & $1,00 \times 10^{-10}$ & 84,082 \\
\hline 10 & 20 & 0,0001 & 0,01 & $1,00 \times 10^{-10}$ & 98,096 \\
\hline 11 & 20 & 0,0001 & 0,3 & $1,00 \times 10^{-10}$ & 96,434 \\
\hline 12 & 30 & 0,00001 & 0,00001 & $1,00 \times 10^{-7}$ & 92,857 \\
\hline 13 & 30 & 0,00001 & 0,0001 & $1,00 \times 10^{-7}$ & 93,229 \\
\hline 14 & 30 & 0,00001 & 0,001 & $1,00 \times 10^{-7}$ & 92,270 \\
\hline 15 & 50 & 0,00001 & 0,00001 & $1,00 \times 10^{-7}$ & 94,467 \\
\hline 16 & 50 & 0,00001 & 0,0001 & $1,00 \times 10^{-7}$ & 93,159 \\
\hline 17 & 50 & 0,00001 & 0,001 & $1,00 \times 10^{-7}$ & 92,880 \\
\hline 18 & 70 & 0,00001 & 0,00001 & $1,00 \times 10^{-7}$ & 96,277 \\
\hline 19 & 70 & 0,00001 & 0,0001 & $1,00 \times 10^{-7}$ & 96,380 \\
\hline 20 & 70 & 0,00001 & 0,001 & $1,00 \times 10^{-7}$ & 97,355 \\
\hline 21 & 90 & 0,00001 & 0,00001 & $1,00 \times 10^{-7}$ & 95,502 \\
\hline 22 & 90 & 0,00001 & 0,0001 & $1,00 \times 10^{-7}$ & 98,826 \\
\hline 23 & 90 & 0,00001 & 0,001 & $1,00 \times 10^{-7}$ & 91,614 \\
\hline
\end{tabular}

Pada pengujian data uji, hasil tingkat akurasi tidak sebesar hasil uji pada data latih, hal ini wajar terjadi karena data latih merupakan data yang telah melalui proses pelatihan dan pembobotan yang dibimbing untuk mendekati nilai target, sedangkan data uji tidak melalui proses pelatihan. Tabel 3 menunjukkan bahwa hasil tingkat akurasi terbaik dihasilkan pada kombinasi nilai parameter dengan jumlah neuron sebanyak 90, galat 0,00001 , laju pembelajaran 0,0001 dengan gradien minimum $1,00 \times 10^{-7}$ yaitu sebesar $98,826 \%$. Sedangkan hasil akurasi terendah dihasilkan pada kombinasi nilai parameter dengan jumlah neuron 10 , galat 0 , laju pembelajaran 0,01 dengan gradien minimum $1,00 \times 10^{-10}$ yaitu sebesar $53,886 \%$. Beberapa faktor tentu sangat mempengaruhi hasil akurasi data, jaringan dengan nilai parameter galat 0 memerlukan iterasi yang lebih banyak dibandingkan dengan galat bernilai 0,0001. Hal tersebut dikarenakan jaringan akan terus dilatih sampai target benar-benar ditemukan dan memiliki galat 0 .

\subsection{Pengujian Data Uji Dua Lapisan Tersembunyi}

Pengujian data uji dua lapisan tersembunyi dilakukan untuk mengetahui apakah penambahan lapisan tersembunyi mempengaruhi tingkat akurasi prediksi untuk data uji atau tidak. Pada Tabel 4 ditunjukkan hasilnya sebagai berikut. 
Tabel 4 Hasil Pengujian Data Uji Dua Lapisan Tersembunyi

\begin{tabular}{|c|c|c|c|c|c|c|}
\hline \multirow{3}{*}{ No. } & \multicolumn{5}{|c|}{ Parameter Pelatihan } & \multirow[t]{3}{*}{$\begin{array}{c}\text { Hasil } \\
\text { Akuras } \\
(\%)\end{array}$} \\
\hline & \multicolumn{2}{|c|}{$\begin{array}{c}\text { Lapisan } \\
\text { Tersembunyi }\end{array}$} & \multirow[t]{2}{*}{ Galat } & \multirow[t]{2}{*}{$\begin{array}{c}\text { Laju } \\
\text { Pembelajaran }\end{array}$} & \multirow[t]{2}{*}{$\begin{array}{r}\text { Gradien } \\
\text { Minimum }\end{array}$} & \\
\hline & I & II & & & & \\
\hline 1 & 10 & 10 & 0 & 0,01 & $1,00 \times 10^{-20}$ & 60,873 \\
\hline 2 & 10 & 10 & 0 & 0,3 & $1,00 \times 10^{-10}$ & 80,100 \\
\hline 3 & 10 & 10 & 0,0001 & 0,01 & $1,00 \times 10^{-10}$ & 93,283 \\
\hline 4 & 10 & 10 & 0,0001 & 0,3 & $1,00 \times 10^{-10}$ & 97,863 \\
\hline 5 & 10 & 10 & 0,00001 & 0,00001 & $1,00 \times 10^{-7}$ & 96,147 \\
\hline 6 & 10 & 10 & 0,00001 & 0,0001 & $1,00 \times 10^{-7}$ & 92,774 \\
\hline 7 & 10 & 10 & 0,00001 & 0,001 & $1,00 \times 10^{-7}$ & 97,120 \\
\hline 8 & 10 & 20 & 0 & 0,01 & $1,00 \times 10^{-20}$ & 91,966 \\
\hline 9 & 10 & 20 & 0 & 0,3 & $1,00 \times 10^{-20}$ & 81,824 \\
\hline 10 & 10 & 20 & 0,0001 & 0,01 & $1,00 \times 10^{-10}$ & 96,598 \\
\hline 11 & 10 & 20 & 0,0001 & 0,3 & $1,00 \times 10^{-20}$ & 97,385 \\
\hline 12 & 10 & 30 & 0,00001 & 0,00001 & $1,00 \times 10^{-7}$ & 98,849 \\
\hline 13 & 10 & 30 & 0,00001 & 0,0001 & $1,00 \times 10^{-7}$ & 91,571 \\
\hline 14 & 10 & 30 & 0,00001 & 0,001 & $1,00 \times 10^{-7}$ & 97,760 \\
\hline 15 & 10 & 50 & 0,00001 & 0,00001 & $1,00 \times 10^{-7}$ & 97,661 \\
\hline 16 & 10 & 50 & 0,00001 & 0,0001 & $1,00 \times 10^{-7}$ & 96,692 \\
\hline 17 & 10 & 50 & 0,00001 & 0,001 & $1,00 \times 10^{-7}$ & 93,449 \\
\hline 18 & 20 & 10 & 0 & 0,01 & $1,00 \times 10^{-10}$ & 79,635 \\
\hline 19 & 20 & 10 & 0 & 0,3 & $1,00 \times 10^{-10}$ & 89,259 \\
\hline 20 & 20 & 10 & 0,0001 & 0,01 & $1,00 \times 10^{-20}$ & 97,567 \\
\hline 21 & 20 & 10 & 0,0001 & 0,3 & $1,00 \times 10^{-10}$ & 96,963 \\
\hline 22 & 20 & 20 & 0 & 0,01 & $1,00 \times 10^{-20}$ & 67,037 \\
\hline 23 & 20 & 20 & 0 & 0,3 & $1,00 \times 10^{-10}$ & 93,483 \\
\hline 24 & 20 & 20 & 0,0001 & 0,01 & $1,00 \times 10^{-10}$ & 98,605 \\
\hline 25 & 20 & 20 & 0,0001 & 0,3 & $1,00 \times 10^{-20}$ & 94,236 \\
\hline 26 & 30 & 10 & 0,00001 & 0,00001 & $1,00 \times 10^{-7}$ & 98,583 \\
\hline 27 & 30 & 10 & 0,00001 & 0,0001 & $1,00 \times 10^{-7}$ & 96,031 \\
\hline 28 & 30 & 10 & 0,00001 & 0,001 & $1,00 \times 10^{-7}$ & 94,851 \\
\hline 29 & 30 & 30 & 0,00001 & 0,00001 & $1,00 \times 10^{-7}$ & 95,282 \\
\hline 30 & 30 & 30 & 0,00001 & 0,0001 & $1,00 \times 10^{-7}$ & 97,392 \\
\hline 31 & 30 & 30 & 0,00001 & 0,001 & $1,00 \times 10^{-7}$ & 97,645 \\
\hline 32 & 30 & 50 & 0,00001 & 0,00001 & $1,00 \times 10^{-7}$ & 97,697 \\
\hline 33 & 30 & 50 & 0,00001 & 0,0001 & $1,00 \times 10^{-7}$ & 96,425 \\
\hline 34 & 30 & 50 & 0,00001 & 0,001 & $1,00 \times 10^{-7}$ & 98,448 \\
\hline 35 & 50 & 10 & 0,00001 & 0,00001 & $1,00 \times 10^{-7}$ & 93,405 \\
\hline 36 & 50 & 10 & 0,00001 & 0,0001 & $1,00 \times 10^{-7}$ & 93,153 \\
\hline 37 & 50 & 10 & 0,00001 & 0,001 & $1,00 \times 10^{-7}$ & 91,350 \\
\hline 38 & 50 & 30 & 0,00001 & 0,00001 & $1,00 \times 10^{-7}$ & 96,730 \\
\hline 39 & 50 & 30 & 0,00001 & 0,0001 & $1,00 \times 10^{-7}$ & 97,560 \\
\hline 40 & 50 & 30 & 0,00001 & 0,001 & $1,00 \times 10^{-7}$ & 96,595 \\
\hline 41 & 50 & 50 & 0,00001 & 0,00001 & $1,00 \times 10^{-7}$ & 95,947 \\
\hline 42 & 50 & 50 & 0,00001 & 0,0001 & $1,00 \times 10^{-7}$ & 94,055 \\
\hline 43 & 50 & 50 & 0,00001 & 0,001 & $1,00 \times 10^{-7}$ & 96,249 \\
\hline 44 & 70 & 10 & 0,00001 & 0,00001 & $1,00 \times 10^{-7}$ & 97,415 \\
\hline 45 & 70 & 10 & 0,00001 & 0,0001 & $1,00 \times 10^{-7}$ & 98,798 \\
\hline 46 & 70 & 10 & 0,00001 & 0,001 & $1,00 \times 10^{-7}$ & 94,222 \\
\hline 47 & 70 & 30 & 0,00001 & 0,00001 & $1,00 \times 10^{-7}$ & 96,745 \\
\hline 48 & 70 & 30 & 0,00001 & 0,0001 & $1,00 \times 10^{-7}$ & 97,313 \\
\hline 49 & 70 & 30 & 0,00001 & 0,001 & $1,00 \times 10^{-7}$ & 96,833 \\
\hline 50 & 70 & 50 & 0,00001 & 0,00001 & $1,00 \times 10^{-7}$ & 96,839 \\
\hline 51 & 70 & 50 & 0,00001 & 0,0001 & $1,00 \times 10^{-7}$ & 97,514 \\
\hline 52 & 70 & 50 & 0,00001 & 0,001 & $1,00 \times 10^{-7}$ & 95,061 \\
\hline 53 & 90 & 10 & 0,00001 & 0,00001 & $1,00 \times 10^{-7}$ & 95,593 \\
\hline 54 & 90 & 10 & 0,00001 & 0,0001 & $1,00 \times 10^{-7}$ & 96,255 \\
\hline 55 & 90 & 10 & 0,00001 & 0,001 & $1,00 \times 10^{-7}$ & 97,689 \\
\hline 56 & 90 & 30 & 0,00001 & 0,00001 & $1,00 \times 10^{-7}$ & 95,601 \\
\hline 57 & 90 & 30 & 0,00001 & 0,0001 & $1,00 \times 10^{-7}$ & 97,517 \\
\hline 58 & 90 & 30 & 0,00001 & 0,001 & $1,00 \times 10^{-7}$ & 97,941 \\
\hline 59 & 90 & 50 & 0,00001 & 0,00001 & $1,00 \times 10^{-7}$ & 96,597 \\
\hline 60 & 90 & 50 & 0,00001 & 0,0001 & $1,00 \times 10^{-7}$ & 94,176 \\
\hline 61 & 90 & 50 & 0,00001 & 0,001 & $1,00 \times 10^{-7}$ & 95,518 \\
\hline
\end{tabular}

Tabel 4 menunjukkan bahwa hasil tingkat akurasi terbaik untuk data uji adalah pada kombinasi neuron 10-30 dengan galat 0,00001 dan laju pembelajaran sebesar 0,00001 yaitu dengan hasil akurasi sebesar $98,849 \%$. Sedangkan untuk hasil tingkat akurasi terendah terdapat pada kombinasi neuron 10-10 dengan galat 0 dan laju pembelajaran sebesar 0,01 yaitu dengan hasil akurasi sebesar 60,873\%.

Dari percobaan yang telah dilakukan, kita dapat menentukan arsitektur yang terbaik untuk melakukan prediksi harga logam mulia emas yaitu arsitektur dengan rata-rata antara hasil akurasi data latih dan data uji yang paling tinggi.

Dengan demikian, jaringan yang memiliki hasil rata-rata akurasi terbaik untuk data latih dan data uji adalah jaringan dengan kombinasi nilai parameter dengan dua lapisan tersembunyi, neuron 10-30, galat sebesar 0,00001, laju pembelajaran sebesar 0,00001 dan nilai gradien minimum sebesar $1,00 \times 10^{-7}$ dengan akurasi data latih $99,760 \%$ dan akurasi data uji $98,849 \%$

\section{Kesimpulan}

Kesimpulan yang dapat diambil dari hasil pengujian dan pembahasan dari tiap-tiap jaringan adalah sebagai berikut.

1. Jaringan syaraf tiruan melakukan proses peramalan melalui pelatihan dengan nilainilai parameter pelatihan jaringan dan mengenali pola dari pergerakan data masa lalu.

2. Parameter-parameter pada JST saling mempengaruhi hasil tingkat akurasi data, kombinasi yang seimbang akan menghasilkan akurasi yang baik.

3. Nilai parameter galat berpengaruh terhadap hasil akurasi data uji karena jika pada saat pelatihan jaringan nilai parameter galat tidak terpenuhi maka hasil pengujian terhadap data uji akan menghasilkan hasil akurasi yang rendah.

4. Arsitektur JST yang paling tepat untuk prediksi harga logam mulia adalah asritektur dengan hasil akurasi antara data latih dan data uji yang memiliki selisih paling rendah yaitu dengan hasil akurasi data latih sebesar $99,760 \%$ dan data uji sebesar $98,849 \%$ yang dimiliki oleh jaringan dengan arsitektur dua lapisan tersembunyi kombinasi neuron 10-30, galat sebesar 0,00001 dan laju pembelajaran sebesar 0,00001.

5. Aplikasi jaringan syaraf tiruan perambatan balik untuk memprediksi harga logam mulia emas ini dapat digunakan secara real time.

Dari kesimpulan tersebut, penulis memberikan saran sebagai berikut.

1. Perlu dilakukan penelitian lanjutan dengan kombinasi parameter yang lebih baik 
sehingga akan menghasilkan akurasi data latih dan data uji yang lebih tinggi.

2. Perlu dilakukan penelitian lanjutan dengan jumlah data yang lebih banyak sehingga lonjakan harga akan lebih bervariasi, misalkan data lima tahunan.

\section{Daftar Pustaka}

[1] Sunariyah, "Pengantar Pengetahuan Pasar Modal", UPP APM YKPN, Yogyakarta, 2003.

[2] Roy Sembel, "Investasi Emas", Kontan, Maret 2008, hal 12.

[3] Pangestuti, Sri, "Analisis Return LQ45 Dibandingkan Return Emas dan faktorFaktor Yang mempengaruhi Return LQ45 dan Return Emas Selama Periode 1995 2010”, Thesis-S2, 2010.

[4] Rahardja, Prathama, "Uang dan Perbankan”, Rineka Cipta, Jakarta, 1997.

[5] Baswara, Sastya Yoga, "Analisis Nilai Hasil Investasi Deposito Rupiah, Deposito Dolar Amerika dan Dinar Emas dengan Emas sebagai Alat Ukur", Skripsi-S1, Universitas Diponegoro, Semarang, 2012.

[6] Hermawan, Arief "Jaringan Syaraf TiruanTeori dan Aplikasi”, Andi, Yogyakarta, 2006.

[7] Siang, J. J., "Jaringan Syaraf Tiruan \& Pemrogramannya Menggunakan MATLAB”, Penerbit Andi, Yogyakarta, 2009.

[8] Kusumadewi, S. dan S. Hartati, “ NEUROFUZZY Integrasi Sistem Fuzzy dan Jaringan Saraf edisi 2", Graha Ilmu, Yogyakarta, 2010.

[9] Fausett, Laurene V, "Fundamentals of Neural Networks: Architectures, Algorithms, and Applications", J. N., 1994.

[10] Rahmat, dkk, "Perbandingan Algoritma Levenberg Marquardt dengan Metoda Backpropagation pada Proses Learning Jaringan Saraf Tiruan untuk Pengenalan Pola Sinyal Elektrokardiograf", Seminar Nasional Aplikasi Teknologi Informasi 2006 (SNATI 2006), Yogyakarta, 17 Juni 2006.

[11] -- Levenberg Marquardt Backpropagation. http://www.mathworks.com/help/nnet/ref/trai nlm.html.

[12] Nugroho, Gathut, “Aplikasi Jaringan Syaraf Tiruan dengan Metode Perambatan Balik untuk Peramalan Harga Dinar dan Dirham", Skripsi-S1, Universitas Diponegoro, Semarang, 2012.

\section{Biografi Penulis}

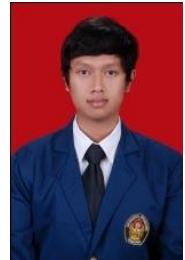

Reza Najib Hidayat lahir di Temanggung, 25 Oktober 1989. Memulai pendidikan di SD N Bulu Lor 04, SMP N 7 Semarang, SMA N 6 Semarang. Saat ini penulis sedang menempuh pendidikan $\mathrm{S} 1$ di program studi Sistem Komputer, Fakultas Teknik, Universitas Diponegoro angkatan 2008. 